\title{
VEGETATIVE AND PRODUCTIVE RESPONSES OF ORGANIC APPLE (Malus domestica L.) TO FOSSILIZED RED GUANO AND A CONTROLLED-RELEASE FERTILIZER
}

\section{RESPUESTAS VEGETATIVAS Y PRODUCTIVAS DE MANZANOS ORGÁNICOS (Malus domestica L.) A LA FERTILIZACIÓN CON GUANO ROJO FOSILIZADO Y UN FERTILIZANTE DE ENTREGA CONTROLADA}

\author{
Eduardo von Bennewitz ${ }^{1,2 *}$, Rodrigo Cazanga-Solar ${ }^{4}$, Marcos Carrasco-Benavides ${ }^{3}$, Claudio Fredes ${ }^{3}$, \\ Jhonny Edison Alba-Mejía ${ }^{5}$, and Tomas Lošak ${ }^{2}$ \\ ${ }^{1}$ Universidad Austral Chile, Inst. Plant Prod and Protect, Campus Isla Teja, Valdivia, Chile \\ ${ }^{2}$ Mendel University in Brno, Faculty of Regional Development and International Studies, Trída \\ Generála Píky 2005/7. Brno - Cerná Pole 613 00, Czech Republic. \\ ${ }^{3}$ Universidad Católica del Maule, Escuela de Agronomía, Camino a los Niches km 5, Curicó, Chile. \\ ${ }^{4}$ Universidad de Chile, Laboratorio de Investigación de Ciencias Ambientales (LARES), Av. Santa \\ Rosa 11315, La Pintana, Santiago, Chile. \\ ${ }^{5}$ Mendel University in Brno, Faculty of AgriSciences, Department of Animal Nutrition and Forage \\ Production, Zemedelska 1, Brno - Cerná Pole 613 00, Czech Republic. \\ *Corresponding autor E-mail:eduardo.alvarez@mendelu.cz
}

\section{RESUMEN}

El guano rojo fosilizado y los fertilizantes orgánicos de entrega controlada están dentro de los fertilizantes que se pueden usar en producción orgánica. Existe poca información sobre los impactos de estos fertilizantes sobre el crecimiento, productividad, calidad y composición mineral de la fruta. El objetivo de este estudio fue evaluar el efecto de niveles crecientes de fertilización nitrogenada con guano rojo y un fertilizante de entrega controlada (Fertil ${ }^{\circledR}$ ), sobre el crecimiento vegetativo, el rendimiento, concentración mineral en hojas, la calidad y composición mineral de frutos, en manzanas 'Granny Smith' cultivadas con manejo orgánico. Los tratamientos incluyeron el uso de niveles crecientes de $\mathrm{N}\left(100 ; 120 ;\right.$ y $\left.170 \mathrm{~kg} \mathrm{~N} \mathrm{ha}^{-1}\right)$ aplicados en 2 parcialidades: $50 \%$ a inicios de primavera, y $50 \%$ a inicios del verano. En general, los árboles que recibieron dosis más altas de $\mathrm{N}$ presentaron un mayor crecimiento de brotes terminales y sección transversal de tronco (STT) respecto del control. El rendimiento (entre 60,0 y $62,0 \mathrm{~kg}^{2}$ árbol $^{-1}$ ), la concentración mineral y las relaciones minerales en frutos tampoco se vieron afectadas por los tratamientos. Las concentraciones foliares de minerales fueron afectadas en el caso de $\mathrm{N}$. Se detectó bitter pit sólo en un nivel bajo (1,4 en una escala de 1 a 4) no significativo estadísticamente. Bajo las condiciones estudiadas, ambos fertilizantes demostraron ser efectivos en aumentar el crecimiento vegetativo, respecto del control, pero no influyeron sobre el rendimiento, firmeza del frutos, contenido de solidos solubles, color de fondo y la incidencia de desórdenes fisiológicos.

Palabras clave: Producción orgánica, fertilizantes orgánicos, desórdenes fisiológicos, contenido mineral 


\section{ABSTRACT}

Fossilized red guano and organic controlled-release fertilizers are among the $\mathbf{N}$ fertilizers that can be used in organic production. There is little information about the impacts of these fertilizers on the vegetative growth, fruit yield and quality, and mineral contents in fruits. The objective of this study was to assess the responses of increasing levels of $\mathrm{N}$ fertilization with fossilized red guano and a controlled-release fertilizer $\left(\right.$ Fertil $\left.^{\circledR}\right)$ on the vegetative growth, fruit yield, quality and mineral composition of 'Granny Smith' apples grown under organic management. Treatments included the application of increasing levels of $\mathrm{N}$ fertilization $\left(100,120\right.$ and $170 \mathrm{~kg} \mathrm{~N} \mathrm{ha}^{-1}$ ) applied $50 \%$ during early spring and $50 \%$ during early summer. In general, trees with higher levels of $\mathrm{N}$ fertilization showed greater terminal shoot length and trunk cross-sectional area (TCSA) than those of the control treatment. Yield ranged from 60.0 to $62.0 \mathrm{~kg} \mathrm{tree}^{-1}$, as well as fruit mineral concentration and ratios were not affected by the treatments. Leaf mineral concentrations were affected only in the case of N. Bitter pit incidence was low (1.4 in a scale 1-4), and therefore not statistically significant. Both fertilizers proved effective in enhancing vegetative growth compared to the control. Fertilizer applications did not affect tree cropping, fruit firmness, TSS, starch index, fruit ground color and incidence of physiological disorders.

Key words: Organic fruit production, organic fertilizers, physiological disorders, mineral content

\section{INTRODUCTION}

The protection of long-term soil fertility and essential nutrient supply to the trees through natural or organic fertilizers are among the key principles and practices of organic farm management (Herencia et al., 2007). Organic orchards with increased soil biological activity and slow-released nutrient sources may respond differently than conventional ones (Choi et al., 2011). N fertilizers vary widely in cost, $\mathrm{N}$ content, and $\mathrm{N}$ availability (Gaskell and Smith, 2007). Red guano and blood meal are among the allowed $\mathrm{N}$ organic amendments. These have been widely used in Chilean organic agriculture. Herencia et al. (2007) described that these $\mathrm{N}$ organic amendments may improve soil fertility, but that it is difficult to estimate their nutritional impact on the crop due to their inconsistent composition. In many cases, growers tend to apply high amounts of organic $\mathrm{N}$ sources in organic apple production in order to supply adequate nitrogen to meet the needs of apple trees. This may lead to an oversupply of $\mathrm{N}$, generating excessive vigour and poor quality characteristics derived from a greater incidence of storage disorders, such as bitter pit, among others (Nava and Dechen, 2009; De Freitas and Mitcham, 2012).

On the other hand, if organic fertilizers have a lower nutrient level or do not contain readily soluble nitrogen, the amount and rate of release, as well as the rate of uptake, may be slowed or altered (Choi et al., 2011). Few studies on N nutrition in organic apple tree orchards have been conducted in Chile (Von Bennewitz et al., 2015) and there is even less information available on the impact of organic and controlled-release fertilizers like fossilized red guano and Fertil ${ }^{\circledR}$, on growth, fruit yield, quality of apples and mineral composition. Fossilized red guano (FRG, 2.5\% N) consists of nitrogen-ammonium oxalate, urate and phosphates originated from excrement of seabirds, seals, or cave-dwelling bats. Fertil ${ }^{\circledast}(12.5 \% \mathrm{~N})$ is a controlled-release N organic fertilizer (CRF) composed of a granulated polymer $(1-3 \mathrm{~mm})\left(\right.$ Agrogel $\left.^{\circledR}\right)$ which has being extensively used in Chilean organic agriculture.

Based on the described above, the objective of our research was to evaluate the effect of increasing $\mathrm{N}$ levels of two $\mathrm{N}$ organic fertilizers on vegetative growth, fruit yield, quality and mineral composition of organically grown 'Granny Smith' apples.

\section{MATERIALS AND METHODS}

\section{Study site, cultural practices and treatment applications}

The study was carried out during 2012 and 2013 in the Maule Region of Chile (35을 $15.55^{\prime \prime}$ S; 71ำ $\left.11^{\prime} 5.42^{\prime \prime} \mathrm{W}\right)$. The soil at the site was a loam, $0.8 \mathrm{~m}$ depth that belongs to the Romeral soil Series (Humic Haploxerands) (Casanova et al., 2007). Soil mineral analysis $(0-0.20 \mathrm{~m})$ showed the following results: available $\mathrm{N}\left(11 \mathrm{mg} \mathrm{kg}^{-1}\right), \mathrm{K}(201$ $\left.\mathrm{mg} \mathrm{kg}^{-1}\right), \mathrm{P}\left(11 \mathrm{mg} \mathrm{kg}^{-1}\right), \mathrm{Ca}\left(8.47 \mathrm{cmol}_{\mathrm{c}} \mathrm{kg}^{-1}\right), \mathrm{Mg}$ $\left(2.44 \mathrm{cmol}_{\mathrm{c}} \mathrm{kg}^{-1}\right), \mathrm{Na}\left(0.35 \mathrm{cmol}_{\mathrm{c}} \mathrm{kg}^{-1}\right), \mathrm{Zn}(4.90$ $\left.\mathrm{mg} \mathrm{kg}^{-1}\right)$, Mn $\left(4.90 \mathrm{mg} \mathrm{kg}^{-1}\right)$, Fe $\left(40.00 \mathrm{mg} \mathrm{kg}^{-1}\right)$, B (2.40 mg kg-1), $\mathrm{pH}-\mathrm{H}_{2} \mathrm{O}$ (6.2), O.M (6.1\%), CEC $\left(17.75 \mathrm{cmol}_{\mathrm{c}} \mathrm{kg}^{-1}\right)$, EC $\left(0.16 \mathrm{dS} \mathrm{m}^{-1}\right)$. The climate of the region is characterized as Mediterranean. Mean annual temperature in the region is $15^{\circ} \mathrm{C}$ and mean annual precipitation is $700 \mathrm{~mm}$. Plant material consists of 'Granny Smith' apple trees, 
planted in 1998 on 'MM 106' rootstock. Tree are trained to a 'Solaxe' system (Lauri and Lespinasse, 1999) and spaced $4 \times 2 \mathrm{~m}$ in North to South row $\left(1,250\right.$ trees $\left.\mathrm{ha}^{-1}\right)$. Trees have been organically grown since 2005.

All sample trees were of uniform size and without any visible symptoms of either disease or pest infestation at the time of trial initiation. Organic allowed cultural practices were followed every year and trees were irrigated with undertree microsprinklers on a weekly basis during summer. Treatments included the application of three increasing levels of $\mathrm{N}$ fertilization (100; 120; and $170 \mathrm{~kg} \mathrm{~N} \mathrm{ha}^{-1}$ ) incorporated as fossilized red guano $(2.5 \% \mathrm{~N})$, the controlled released fertilizer Fertil ${ }^{\circledast}(12.5 \% \mathrm{~N})$ and a mixture of both. A completely randomized design was used, with ten individual trees as replications. Fossilized red guano (FRG, 2.5\% N) consists of nitrogenammonium oxalate, urate and phosphates originated from excrement of seabirds, seals, or cave-dwelling bats. Fertil ${ }^{\circledR}(12.5 \% \mathrm{~N})$ is a controlled-release $\mathrm{N}$ organic fertilizer composed of a granulated polymer $(1-3 \mathrm{~mm})\left(\right.$ Agrogel $\left.^{\circledR}\right)$. It is produced in Europe by the ILSA Company (Italy) according to EU regulation 453/2010. These fertilizers have being extensively used in Chilean organic agriculture.

Treatments and total amounts used for each organic fertilizer are presented in Table 1.

FRG 100 was used as a control treatment because this was the usual dose applied in the orchard under study for many years. Doses of 120 and $170 \mathrm{~kg} \mathrm{~N} \mathrm{ha}^{-1}$ were used in each treatment, except for the control treatment. Not all possible combinations were tested due to resources and time constraints. This undoubtedly implies limitations for the present study. $\mathrm{N}$ organic fertilizers were applied in a 0.9 radius around the tree trunk (50\% during early spring and 50\% during early summer), and then incorporated with soil and watered. Four main uniform branches at the four cardinal points of each experimental tree were tagged to evaluate the following vegetative growth parameters during 2012 and 2013: terminal shoot length, spur length and trunk cross-sectional area (TCSA). Terminal shoot length was measured each year during midDecember. Spur length $(\mathrm{cm})$ was measured in ten tagged spurs in each of the four selected branches per tree during January. For the trunk crosssectional area (TCSA), the trunk circumference (C) was measured $0.20 \mathrm{~m}$ above the soil line each year at harvest, and the TCSA was calculated using the following formula: TCSA $=\mathrm{C}^{2} / 4 \pi$ (Von Bennewitz et al., 2011).

Fruit was harvested when the Streif index [firmness/ (percentage soluble solids concentration $\times$ starch index)] (Streif, 1996) showed values over 0.35 . The crop from each tree and branch cross sectional area (BCSA) were measured at harvest. Fruit yield was measured separately for each tree and branch. The yield efficiency was calculated as: $\mathrm{kg}$ of fruit/BCSA $\left(\mathrm{cm}^{2}\right)$, fruit number/tree, $\mathrm{kg}$ fruit/tree, and mean fruit weight $(\mathrm{kg})$.

Apple fruits were stored for 30 and 60 days in refrigerated-air storage at $1-2^{\circ} \mathrm{C}$ and a relative air humidity of $88-90 \%$. Fruit firmness, total soluble solids (TSS) and the incidence of physiological disorders were assessed at harvest and after fruit was removed from storage (30 and 60 days). Total soluble solids (TSS) was determined using an Atago-1 hand held refractometer and expressed as ${ }^{\circ}$ Brix. Fruit firmness was measured on 12 fruits using a Mc-Cormick firmness-tester (11-mm tip). Starch index of fruit was estimated by iodine test using a scale of $1(100 \%$ of cross section area stained) to 10 ( $0 \%$ of area stained). The incidence of physiological disorders (bitter pit, water core, internal breakdown, scald) was assessed using a 1 to 4 scale developed by Von Bennewitz et al. (2011). For bitter pit: level 1, healthy fruit; level 2 , when the fruit had between 1 and 6 pits on its surface; level 3, or moderate, when less than onethird of the surface of the fruit was affected; and

Table 1. Rates and combinations of each fertilizer of $\mathbf{N}$ treatments in organically cultivated apple trees.

\begin{tabular}{|c|c|c|c|c|c|}
\hline Treatment & Total N & $\begin{array}{l}\text { Fossilized } \\
\text { red guano }\end{array}$ & Fertil $^{\circledR}$ & $\begin{array}{l}\text { Fossilized } \\
\text { red guano } \\
(2.5 \% \mathrm{~N})\end{array}$ & $\begin{array}{l}\text { Fertil }^{\circledR} \\
(12.5 \% \text { N) }\end{array}$ \\
\hline & ----- & $N\left(\mathrm{~kg} \mathrm{ha}^{-1}\right)$ & ------- & \multicolumn{2}{|c|}{------- kg ha-1 ------ } \\
\hline FRG 100 (Control) & 100.0 & 100.0 & 0.0 & $4,000.0$ & 0.0 \\
\hline Fertil $^{\circledR} 120$ & 120.0 & 0.0 & 120.0 & 0.0 & 960.0 \\
\hline FRG 170 & 170.0 & 170.0 & 0.0 & $6,800.0$ & 0.0 \\
\hline Ferti $^{\circledR} 170$ & 170.0 & 0.0 & 170.0 & 0.0 & $1,360.0$ \\
\hline Fertil $^{\circledR} 60$ + FRG 60 & 120.0 & 60.0 & 60.0 & $2,400.0$ & 480.6 \\
\hline
\end{tabular}

FRG: Fossilized red guano 
level 4, or severe, when more than one-third of the surface of the fruit was affected.

Fruit mineral analyses were carried out during the second year of the study (2013). Nitrogen was determined according to the Kjeldahl method. In order to determine $\mathrm{P}, \mathrm{K}, \mathrm{Ca}$, and $\mathrm{Mg}$, fruit samples were digested in 9:1 $(\mathrm{v}=\mathrm{v})$ mixture of $\mathrm{HNO}_{3}$ and $\mathrm{HClO}_{4}$ or ashed in a muffle furnace at $480^{\circ} \mathrm{C}$ for 12 hours. P was determined colorimetrically by the vanado-molybdo-phosphoric method, while Boron, Potassium, Magnesium and Calcium were determined using an atomic absorption spectrophotometer (Perkin Elmer AAnalyst 400, Waltham, USA). Concentrations of nutrients in fruit tissues were expressed on a dry weight (DW) basis. In the case of leaf analysis, leaves were collected from the mid-region of current season shoots after terminal bud formation in midJanuary. Leaves were washed in detergent, rinsed in deionized water, dried at $65{ }^{\circ} \mathrm{C}$, and ground in a grinder. Wet digestion was used for organic matter destruction in the case of N, P, K, Ca, Mg and dry ashing for $\mathrm{Fe}, \mathrm{Mn}, \mathrm{Cu}$ and $\mathrm{Zn}$. Results were subject to analysis of variance (ANOVA), mean separation was done by Tukey's multiple range test at $5 \%$ level of significance (Vaugham, 2001). Statistical procedures were performed using SAS software (SAS Institute, USA).

\section{RESULTS AND DISCUSSION}

\section{Tree growth, yield and fruit quality}

In general, trees grown under higher levels of $\mathrm{N}$ organic fertilization exhibited greater terminal shoot length and trunk cross-sectional area (TCSA) than those of the control treatment (Table 2). Brunetto et al. (2015) have indicated that the higher the $\mathrm{N}$ availability and uptake, the higher the vegetative growth of apple trees. Spur length was not affected by the treatments during both years. The average seasonal shoot extension growth was $33.5 \mathrm{~cm}$ and $34.5 \mathrm{~cm}$ during the first and second year, respectively. The mean values obtained for these measurements reflect a moderate vigor of this cultivar and an adequate supply of carbohydrates and nutrients required for the extension growth.

Apple tree cropping was not influenced by the treatments during the first (2012) and second year (2013) of the study (Table 3). Average yield was 60.0 and $62.0 \mathrm{~kg}$ tree ${ }^{-1}$ the first and second year, respectively. This represents 75.0 and $77.5 \times 10^{3}$ $\mathrm{kg}$ fruit ha-1 $\left(1,250\right.$ trees ha $\left.{ }^{-1}\right)$. It seems that shoot growth shows a higher response to $\mathrm{N}$ fertilization than to crop productivity as stated by Brunetto et al. (2015). When an increase in fruit yield is not observed after $\mathrm{N}$ fertilization, this may indicate that soil nutrient availability is already within the adequate rate (Mengel and Kirkby, 2001).

The obtained yields may be considered low compared with those observed in conventional apple orchards of the same age and rootstock, where it is possible to reach yields of more than $100 \times 10^{3} \mathrm{~kg}$ fruit ha ${ }^{-1}$. Considering yield efficiency, treatments yielded an average of 0.46 and 0.48 fruits/BCSA $\left(\mathrm{cm}^{2}\right)$. These yield efficiency values may be considered as medium according to Yuri et al. (2008). These authors consider values up to 4 fruits/BCSA $\left(\mathrm{cm}^{2}\right)$ as low fruit load for apples. Regarding mean fruit weight $(\mathrm{kg})$, only a small increase in fruit mean weight was observed for the second season, with values of $0.23 \mathrm{~kg}(2012)$ and $0.25 \mathrm{~kg}$ (2013), respectively. Fruit firmness, starch index and fruit ground color were not affected by $\mathrm{N}$ fertilization during the first and second year at harvest, 30 and 60 days after harvest (Table 4).

Total soluble solids (TSS) were affected by treatments during the second year in the case of the highest dose of fossilized red guano (FRG 170). According to Dris et al. (1999), increased nitrogen

Table 2. Effects of different organic $\mathbf{N}$ fertilization treatments on the vegetative growth of organically grown ‘Granny Smith' apples.

\begin{tabular}{|c|c|c|c|c|c|c|}
\hline \multirow[t]{2}{*}{ Treatments } & \multicolumn{2}{|c|}{$\begin{array}{l}\text { Terminal shoot length } \\
\text { (cm) }\end{array}$} & \multicolumn{2}{|c|}{$\begin{array}{l}\text { Spur length } \\
(\mathrm{cm})\end{array}$} & \multicolumn{2}{|c|}{$\begin{array}{r}\text { TCSA } \\
\left(\mathrm{cm}^{2}\right)\end{array}$} \\
\hline & 2012 & 2013 & 2012 & 2013 & 2012 & 2013 \\
\hline FRG 100 (Control) & $29.3 c$ & $31.4 \mathrm{c}$ & $5.1 \mathrm{a}$ & $5.7 \mathrm{a}$ & $468.3 \mathrm{c}$ & $507.6 \mathrm{c}$ \\
\hline Fertil $^{\circledR} 120$ & $35.0 \mathrm{ab}$ & $36.0 \mathrm{ab}$ & $4.0 \mathrm{a}$ & $4.3 \mathrm{~b}$ & $517.0 \mathrm{~b}$ & $525.0 \mathrm{bc}$ \\
\hline FRG 170 & 35.1 a & $36.2 \mathrm{a}$ & $4.0 \mathrm{a}$ & $4.2 \mathrm{~b}$ & $584.3 \mathrm{a}$ & 597.9 a \\
\hline Fertil ${ }^{\circledR} 170$ & $36.1 \mathrm{a}$ & $37.3 \mathrm{a}$ & $4.4 \mathrm{a}$ & $4.7 \mathrm{~b}$ & $544.9 \mathrm{ab}$ & $556.4 \mathrm{~b}$ \\
\hline Fertil $^{\circledR} 60+$ FRG 60 & $32.0 \mathrm{bc}$ & $33.0 \mathrm{bc}$ & $2.5 \mathrm{a}$ & $2.9 \mathrm{c}$ & $573.0 \mathrm{a}$ & $589.4 \mathrm{a}$ \\
\hline Mean & 33.5 & 34.5 & 4.0 & 4.4 & 545.0 & 525.0 \\
\hline
\end{tabular}

FRG: Fossilized red guano; TCSA: Branch cross-sectional area.

Means followed by the same letter do not differ at at the $5 \%$ level according to Tukey's multiple range test. 
Table 3. Effects of different organic $\mathbf{N}$ fertilization treatment on fruit yield in organically grown 'Granny Smith' apples.

\begin{tabular}{|c|c|c|c|c|c|c|c|c|}
\hline \multirow[t]{2}{*}{ Treatments } & \multicolumn{2}{|c|}{$\begin{array}{c}\mathrm{kg} \text { of fruit/BCSA } \\
\left(\mathrm{cm}^{2}\right)\end{array}$} & \multicolumn{2}{|c|}{ Fruit number/tree } & \multicolumn{2}{|c|}{$\begin{array}{c}\text { Yield } \\
\text { kg/tree }\end{array}$} & \multicolumn{2}{|c|}{$\begin{array}{l}\text { Mean fruit } \\
\text { weight (kg) }\end{array}$} \\
\hline & 2012 & 2013 & 2012 & 2013 & 2012 & 2013 & 2012 & 2013 \\
\hline FRG 100 (Control) & $0.46 \mathrm{a}$ & $0.47 \mathrm{a}$ & $215.4 \mathrm{~b}$ & $233.5 \mathrm{~b}$ & $56.6 \mathrm{a}$ & $58.2 \mathrm{a}$ & $0.21 \mathrm{a}$ & $0.25 \mathrm{a}$ \\
\hline Fertil $^{\circledast} 120$ & $0.47 \mathrm{a}$ & $0.48 \mathrm{a}$ & $243.0 \mathrm{a}$ & $252.0 \mathrm{a}$ & $59.6 \mathrm{a}$ & $62.3 \mathrm{a}$ & $0.24 \mathrm{a}$ & $0.25 \mathrm{a}$ \\
\hline FRG 170 & $0.46 \mathrm{a}$ & $0.49 \mathrm{a}$ & $268.8 \mathrm{a}$ & $272.4 \mathrm{a}$ & $62.0 \mathrm{a}$ & $63.2 \mathrm{a}$ & $0.23 \mathrm{a}$ & $0.23 \mathrm{a}$ \\
\hline Fertil $^{\circledast} 170$ & $0.45 \mathrm{a}$ & $0.49 \mathrm{a}$ & $245.2 \mathrm{a}$ & $255.0 \mathrm{a}$ & $61.8 \mathrm{a}$ & $65.3 \mathrm{a}$ & $0.25 \mathrm{a}$ & $0.26 \mathrm{a}$ \\
\hline Fertil $^{\circledR} 60+$ FRG 60 & $0.46 \mathrm{a}$ & $0.47 \mathrm{a}$ & $263.6 \mathrm{a}$ & $258.2 \mathrm{a}$ & $60.1 \mathrm{a}$ & $61.4 \mathrm{a}$ & $0.24 \mathrm{a}$ & $0.24 \mathrm{a}$ \\
\hline Mean & 0.46 & 0.48 & 247.1 & 254.2 & 60.2 & 62.1 & 0.23 & 0.25 \\
\hline
\end{tabular}

FRG: Fossilized red guano.

Means followed by the same letter do not differ at the $5 \%$ level according to Tukey's multiple range test.

Table 4. Effects of different organic $\mathbf{N}$ fertilization treatments on fruit characteristics in organically cultivated 'Granny Smith' apples at harvest, 30 and 60 days after harvest.

\begin{tabular}{|c|c|c|c|c|c|c|c|c|}
\hline \multirow{2}{*}{$\begin{array}{l}\text { Treatment } \\
\text { Period } \\
\text { At harvest }\end{array}$} & \multicolumn{2}{|c|}{$\begin{array}{c}\text { Firmness } \\
\text { (kg) }\end{array}$} & \multicolumn{2}{|c|}{$\begin{array}{l}\text { TSS } \\
\text { oBrix }\end{array}$} & \multicolumn{2}{|c|}{$\begin{array}{l}\text { Starch index } \\
(1-6)\end{array}$} & \multicolumn{2}{|c|}{$\begin{array}{l}\text { Fruit ground } \\
\text { color } \\
(1-4)\end{array}$} \\
\hline & 2012 & 2013 & 2012 & 2013 & 2012 & 2013 & 2012 & 2013 \\
\hline FRG 100 (Control) & $8.1 \mathrm{a}$ & $7.9 \mathrm{a}$ & $10.7 \mathrm{a}$ & $11.9 \mathrm{ab}$ & $2.0 \mathrm{a}$ & $1.9 \mathrm{~b}$ & $1.1 \mathrm{a}$ & $1.2 \mathrm{a}$ \\
\hline Fertil $^{\circledR} 120$ & $8.1 \mathrm{a}$ & $8.0 \mathrm{a}$ & $10.4 \mathrm{a}$ & $12.4 \mathrm{a}$ & $2.0 \mathrm{a}$ & $2.9 \mathrm{a}$ & $1.1 \mathrm{a}$ & $1.3 \mathrm{a}$ \\
\hline FRG 170 & $7.9 \mathrm{a}$ & $7.9 \mathrm{a}$ & $10.5 \mathrm{a}$ & $11.6 \mathrm{~b}$ & $2.0 \mathrm{a}$ & $2.7 \mathrm{a}$ & $1.1 \mathrm{a}$ & $1.4 \mathrm{a}$ \\
\hline Fertil $^{\circledR} 170$ & $7.8 \mathrm{a}$ & $7.9 \mathrm{a}$ & $10.4 \mathrm{a}$ & $11.8 \mathrm{ab}$ & $2.0 \mathrm{a}$ & $2.7 \mathrm{a}$ & $1.0 \mathrm{a}$ & $1.3 \mathrm{a}$ \\
\hline Fertil $^{\circledR} 60+$ FRG 60 & $8.1 \mathrm{a}$ & $7.8 \mathrm{a}$ & $10.3 \mathrm{a}$ & $11.7 \mathrm{ab}$ & $2.0 \mathrm{a}$ & $2.8 \mathrm{a}$ & $1.0 \mathrm{a}$ & $1.2 \mathrm{a}$ \\
\hline 30 days & 2012 & 2013 & 2012 & 2013 & 2012 & 2013 & 2012 & 2013 \\
\hline FRG 100 (Control) & $8.1 \mathrm{a}$ & $7.5 \mathrm{a}$ & $11.4 \mathrm{a}$ & $12.6 \mathrm{a}$ & $3.0 \mathrm{a}$ & $3.0 \mathrm{a}$ & $1.0 \mathrm{a}$ & $1.1 \mathrm{a}$ \\
\hline Fertil $^{\circledR} 120$ & $8.0 \mathrm{a}$ & $7.4 \mathrm{a}$ & $11.2 \mathrm{a}$ & $12.6 \mathrm{a}$ & $3.0 \mathrm{a}$ & $2.9 \mathrm{a}$ & $1.1 \mathrm{a}$ & $1.2 \mathrm{a}$ \\
\hline FRG 170 & $7.9 \mathrm{a}$ & $7.2 \mathrm{a}$ & $10.3 \mathrm{~b}$ & $11.6 \mathrm{a}$ & $3.0 \mathrm{a}$ & $3.1 \mathrm{a}$ & $1.1 \mathrm{a}$ & $1.2 \mathrm{a}$ \\
\hline Fertil $l^{\circledR} 170$ & $7.8 \mathrm{a}$ & $7.6 \mathrm{a}$ & $11.0 \mathrm{a}$ & $13.1 \mathrm{a}$ & $3.0 \mathrm{a}$ & $3.0 \mathrm{a}$ & $1.0 \mathrm{a}$ & $1.3 \mathrm{a}$ \\
\hline Fertil $^{\circledR} 60$ + FRG 60 & $8.0 \mathrm{a}$ & $7.6 \mathrm{a}$ & $11.1 \mathrm{a}$ & $12.7 \mathrm{a}$ & $3.0 \mathrm{a}$ & $3.0 \mathrm{a}$ & $1.1 \mathrm{a}$ & $1.2 \mathrm{a}$ \\
\hline 60 days & 2012 & 2013 & 2012 & 2013 & 2012 & 2013 & 2012 & 2013 \\
\hline FRG 100 (Control) & $7.7 \mathrm{a}$ & $7.5 \mathrm{a}$ & $13.5 \mathrm{a}$ & $12.8 \mathrm{a}$ & $3.0 \mathrm{a}$ & $2.9 \mathrm{a}$ & $1.1 \mathrm{a}$ & $1.2 \mathrm{a}$ \\
\hline Fertil $^{\circledR} 120$ & $7.7 \mathrm{a}$ & $7.2 \mathrm{a}$ & $13.7 \mathrm{a}$ & $12.6 \mathrm{a}$ & $3.0 \mathrm{a}$ & $3.0 \mathrm{a}$ & $1.1 \mathrm{a}$ & $1.1 \mathrm{a}$ \\
\hline FRG 170 & $7.7 \mathrm{a}$ & $7.3 \mathrm{a}$ & $13.8 \mathrm{a}$ & $13.1 \mathrm{a}$ & $3.0 \mathrm{a}$ & $3.0 \mathrm{a}$ & $1.1 \mathrm{a}$ & $1.1 \mathrm{a}$ \\
\hline Fertil ${ }^{\circledR} 170$ & $7.5 \mathrm{a}$ & $7.5 \mathrm{a}$ & $13.8 \mathrm{a}$ & $12.7 \mathrm{a}$ & $3.0 \mathrm{a}$ & $3.1 \mathrm{a}$ & $1.1 \mathrm{a}$ & $1.3 \mathrm{a}$ \\
\hline Fertil $^{\circledR} 60$ + FRG 60 & $7.8 \mathrm{a}$ & $7.4 \mathrm{a}$ & $13.7 \mathrm{a}$ & $13.0 \mathrm{a}$ & $3.0 \mathrm{a}$ & $3.1 \mathrm{a}$ & $1.1 \mathrm{a}$ & $1.2 \mathrm{a}$ \\
\hline
\end{tabular}

FRG: Fossilized red guano.

Means followed by the same letter do not differ at the $5 \%$ level according to Tukey's multiple range test.

leaf concentrations usually reduce soluble solids levels in apple fruit. This may be explained by the enhanced plant vigor and the related dilution or shading effects (Ferguson and Boyd, 2002).

Evidence of the occurrence of bitter pit was only detected after 60 days of storage in the case of the treatment with the highest dose of $\mathrm{N}(170$ $\left(\mathrm{kg} \mathrm{ha}^{-1}\right)$ applied as Fertil $^{\circledR}$, but in a very low level (1.4 in a scale 1-4). This occurrence did not constitute a significant difference. None of the treatments showed an occurrence of water core, internal breakdown, scald or diseases caused by pathogens. Thus, it seemed that under the present experimental conditions, the increased $\mathrm{N}$ fertilization treatments did not have a significant effect on the most important quality attributes of the fruit.

Fruit mineral concentration and fruit mineral ratios

Results are presented in Table 5.

Nutrients and nutrient ratios have a strong effect on the quality of fruits during storage (Roussos and Gasparatos, 2009). A higher N concentration in 
Table 5. Effects of organic $\mathbf{N}$ fertilization treatments on fruit mineral concentration and fruit mineral ratios.

\begin{tabular}{|c|c|c|c|c|c|c|c|}
\hline Treatments & $\mathbf{N}$ & $\mathbf{P}$ & K & $\mathrm{Ca}$ & Mg & $\mathrm{Zn}$ & B \\
\hline \multicolumn{8}{|c|}{$(\mathrm{mg} \mathrm{100-1}$ g FW) } \\
\hline FRG 100(Control) & $36.9 \mathrm{a}$ & $11.3 \mathrm{a}$ & $123.4 \mathrm{a}$ & $3.4 \mathrm{a}$ & $4.2 \mathrm{a}$ & $0.04 \mathrm{a}$ & $0.51 \mathrm{a}$ \\
\hline Fertil@ 120 & $39.7 \mathrm{a}$ & $12.5 \mathrm{a}$ & $121.6 \mathrm{a}$ & $3.2 \mathrm{a}$ & $3.9 \mathrm{a}$ & $0.05 \mathrm{a}$ & $0.53 \mathrm{a}$ \\
\hline FRG 170 & $45.5 \mathrm{a}$ & $11.9 \mathrm{a}$ & $129.8 \mathrm{a}$ & $3.0 \mathrm{a}$ & $4.1 \mathrm{a}$ & $0.04 \mathrm{a}$ & $0.51 \mathrm{a}$ \\
\hline Fertil $^{\circledR} 170$ & $49.3 \mathrm{a}$ & $12.2 \mathrm{a}$ & $128.8 \mathrm{a}$ & $3.1 \mathrm{a}$ & $4.0 \mathrm{a}$ & $0.03 \mathrm{a}$ & $0.50 \mathrm{a}$ \\
\hline Fertil $^{\circledR} 60+$ FRG 60 & $40.9 \mathrm{a}$ & $12.5 \mathrm{a}$ & $126.1 \mathrm{a}$ & $3.3 \mathrm{a}$ & $4.3 \mathrm{a}$ & $0.03 \mathrm{a}$ & $0.50 \mathrm{a}$ \\
\hline \multirow[t]{2}{*}{ Mean } & 42.5 & 12.1 & 125.9 & 3.2 & 4.1 & 0.04 & 0.50 \\
\hline & $\mathrm{N} / \mathrm{Ca}$ & $\mathrm{K} / \mathrm{Ca}$ & $\mathrm{Mg} / \mathrm{Ca}$ & $\mathrm{K}+\mathrm{Mg} / \mathrm{Ca}$ & $\mathrm{Ca} / \mathrm{Mg}$ & & \\
\hline FRG 100(Control) & $10.8 \mathrm{a}$ & $36.3 \mathrm{a}$ & $1.2 \mathrm{a}$ & $37.5 \mathrm{a}$ & $0.8 \mathrm{a}$ & & \\
\hline Fertil $^{\circledR} 120$ & $12.4 \mathrm{a}$ & $38.0 \mathrm{a}$ & $1.2 \mathrm{a}$ & $39.2 \mathrm{a}$ & $0.8 \mathrm{a}$ & & \\
\hline FRG 170 & $15.9 \mathrm{a}$ & $43.2 \mathrm{a}$ & $1.4 \mathrm{a}$ & $44.6 \mathrm{a}$ & $0.7 \mathrm{a}$ & & \\
\hline Fertil ${ }^{\circledR} 170$ & $12.4 \mathrm{a}$ & $41.5 \mathrm{a}$ & $1.3 \mathrm{a}$ & $42.8 \mathrm{a}$ & $0.8 \mathrm{a}$ & & \\
\hline Fertil $^{\circledast} 60+$ FRG 60 & $12.4 \mathrm{a}$ & $38.2 \mathrm{a}$ & $1.3 \mathrm{a}$ & $39.5 \mathrm{a}$ & $0.8 \mathrm{a}$ & & \\
\hline Mean & $12.7 \mathrm{a}$ & $39.4 \mathrm{a}$ & $1.3 \mathrm{a}$ & $40.7 \mathrm{a}$ & $0.9 \mathrm{a}$ & & \\
\hline
\end{tabular}

FW: Fresh weight; FRG: Fossilized red guano.

Means followed by the same letter do not differ at the $5 \%$ level according to Tukey's multiple range test.

fruits could impair an increase of asparagine, and conversely increase the incidence of bitter pit during storage (Stillianides et al., 2002). In our study, N concentration averaged $42.5 \mathrm{mg} 100 \mathrm{~g}^{-1}$, which may be considered a medium concentration, according to Nielsen and Nielsen (2003). These authors suggested that $\mathrm{N}$ critical nutrient concentration (FW Basis) ranging from $40-70 \mathrm{mg} 100 \mathrm{~g}^{-1}$ can be considered as adequate in apple trees. The low incidence of bitter pit during both years of the study may be explained by this medium $\mathrm{N}$ fruit concentration. The amounts of Ca partitioned into fruits were relatively small. Generally, a threshold value of a minimum Ca requirement (5.0-6.0 mg $\mathrm{Ca}^{-1} 100 \mathrm{~g} \mathrm{FW}$ ) from a mineral analysis of fruit at harvest is used to predict bitter pit levels (Johnson et al., 1987; Nielsen and Nielsen, 2003). Low Ca values have been associated with high risk of bitter pit incidence (Amarante et al., 2006; Saure, 2005). In fact, low Ca fruit concentration together with high $\mathrm{N}$ contents in fruits may increase the incidence of bitter pit development in fruits (Saure, 2005). Ca fruit concentrations (average $0.0032 \%$ DW) reflected adequate levels according to the Ca fruit concentrations thresholds suggested by Ferguson and Watkins (1989), preventing bitter pit (over $0.002 \% \mathrm{DW})$. The very low incidence of physiological disorders associated with $\mathrm{Ca}$ in the fruits under study may be partially explained by these results.

Different authors have also emphasized the importance of mineral ratios in fruits: $\mathrm{N} / \mathrm{Ca}, \mathrm{K} /$
$\mathrm{Ca}, \mathrm{Mg} / \mathrm{Ca}$ and $\mathrm{K}+\mathrm{Mg} / \mathrm{Ca}$ and others for assessing fruit quality (Dris et al., 1999; Piestrzeniewicz and Tomala, 2001). N/Ca ratios in fruits were less than 30 (averaged 12.3), which may be considered as a threshold value for ensuring a good fruit storability (Fallahi et al., 1997). K/Ca ratios reached values over 28 (average 38.2) in most of the cases. This threshold has been recommended by Piestrzeniewicz and Tomala (2001) as a limit for ensuring good fruit quality. Van der Boon (1980) suggested a threshold of $12 \mathrm{~K}+\mathrm{Mg} / \mathrm{Ca}$ to avoid physiological disorders like bitter pit in fruits. High $\mathrm{K} / \mathrm{Ca}$ and $\mathrm{K}+\mathrm{Mg} / \mathrm{Ca}$ ratios in the present study seem to be a risk for the development of physiological disorders like bitter pit in the future.

\section{Leaf mineral concentrations}

Mineral concentrations in leaves were affected only in the case of $\mathrm{N}$ (Table 6). The control treatment showed significantly lower $\mathrm{N}$ leaf concentrations compared to higher $\mathrm{N}$ fertilization treatments. Mineral values indicate normal levels for $\mathrm{N}, \mathrm{P}, \mathrm{K}, \mathrm{Ca}$ and $\mathrm{Mg}$ and high levels of $\mathrm{Mn}, \mathrm{Zn}$, $\mathrm{Cu}, \mathrm{Fe}$ and $\mathrm{B}$ according the standards for apple leaf mineral concentrations provided by Weir and Creswell (1991). 

fertilizer

Table 6. Effects of $\mathbf{N}$ fertilization treatments on mineral concentrations in leaves in organically cultivated 'Granny Smith' apples. Year 2013.

\begin{tabular}{|c|c|c|c|c|c|c|c|c|c|c|}
\hline Treatments & $\mathbf{N}$ & $\mathbf{P}$ & $\begin{array}{c}\text { K } \\
\% \text { DW }\end{array}$ & $\mathrm{Ca}$ & $\mathrm{Mg}$ & Mn & $\mathrm{Zn}$ & $\begin{array}{c}\mathrm{Cu} \\
\left(\mathrm{mg} \mathrm{kg}^{-1}\right)\end{array}$ & $\mathrm{Fe}$ & B \\
\hline FRG 100(Control) & $1.5 \mathrm{~b}$ & $0.2 \mathrm{a}$ & $1.2 \mathrm{a}$ & $1.8 \mathrm{a}$ & $0.3 \mathrm{a}$ & $31.3 \mathrm{a}$ & $15.3 \mathrm{a}$ & $10.3 a$ & $145.4 \mathrm{a}$ & $54.6 \mathrm{a}$ \\
\hline Fertil $^{\circledR} 120$ & $2.0 \mathrm{a}$ & $0.2 \mathrm{a}$ & $1.3 \mathrm{a}$ & $1.8 \mathrm{a}$ & $0.3 \mathrm{a}$ & $30.30 \mathrm{a}$ & $15.2 \mathrm{a}$ & $10.1 \mathrm{a}$ & $146.8 \mathrm{a}$ & $51.2 \mathrm{a}$ \\
\hline FRG 170 & $2.1 \mathrm{a}$ & $0.2 \mathrm{a}$ & $1.2 \mathrm{a}$ & $1.8 \mathrm{a}$ & $0.3 \mathrm{a}$ & $28.4 \mathrm{a}$ & $15.3 \mathrm{a}$ & $10.0 \mathrm{a}$ & $145.4 \mathrm{a}$ & $35.6 \mathrm{a}$ \\
\hline Ferti $^{1 \circledast} 170$ & $2.3 \mathrm{a}$ & $0.2 \mathrm{a}$ & $1.3 \mathrm{a}$ & $1.7 \mathrm{a}$ & $0.3 \mathrm{a}$ & $27.8 \mathrm{~b}$ & $15.3 \mathrm{a}$ & $10.4 \mathrm{a}$ & $148.3 \mathrm{a}$ & $33.7 \mathrm{a}$ \\
\hline Fertil $^{\circledR} 60+$ FRG 60 & $2.0 \mathrm{a}$ & $0.2 \mathrm{a}$ & $1.2 \mathrm{a}$ & $1.8 \mathrm{a}$ & $0.3 \mathrm{a}$ & $31.4 \mathrm{a}$ & $15.3 \mathrm{a}$ & $10.0 \mathrm{a}$ & $127.4 \mathrm{a}$ & $61.5 \mathrm{a}$ \\
\hline Mean & 1.9 & 0.2 & 1.2 & 1.8 & 0.3 & 29.8 & 15.3 & 10.2 & 142.6 & 47.32 \\
\hline
\end{tabular}

FW: Fresh weight; FRG: Fossilized red guano.

Means followed by the same letter do not differ at the $5 \%$ level according to Tukey's multiple range test.

\section{CONCLUSIONS}

Increasing levels of both fertilizers (Fossilized red guano and Fertil $^{\circledR}$ ) proved effective in enhancing vegetative growth (increased terminal shoot length and TCSA) under the studied conditions. Fertilizer applications did not affect tree cropping, major quality attributes of fruit (firmness, TSS, starch index, fruit ground color), incidence of physiological disorders, fruit mineral concentrations and fruit mineral ratios.

\section{LITERATURE CITED}

Amarante, C.V.T., D.V. Chaves, e P.R. Ernani. 2006. Composicão mineral e severidade de bitter pit em macãs 'Catarina'. Revista Brasileira de Fruticultura 28:51-54.

Brunetto, G., G.W.B. Melo, M. De Toselli, M. Quartieri, and M. Tagliavini. 2015. The role of mineral nutrition on yields and fruit quality in grapevine, pear and apple. Revista Brasileira de Fruticultura 37:1089-1104.

Casanova, M., W. Luzio, y R. Maldonado. 2007. Correlación entre World Reference Base y Soil Taxonomy para los suelos de la VII Región del Maule de Chile. Rev. Cienc. Suelo Nutr. Veg. 7:14-21.

Choi, H.S., C.R. Rom, and M. Gu. 2011. Effects of different organic apple production systems on seasonal nutrient variations of soil and leaf. Scientia Horticulturae 129:9-17.

De Freitas, S.T., and E.J. Mitcham. 2012. Factors involved in fruit calcium deficiency disorders. Hortic. Rev. 40:107-146.

Dris, R., R. Niskanen, and E. Fallahi. 1999. Relationship between leaf and fruit minerals and fruit quality attributes of apples grown under northern conditions. Journal of Plant Nutrition 22:1839-1851.
Fallahi, E., W.S. Conway, K.D. Hickey, and C.E. Sams. 1997. The role of calcium and nitrogen in postharvest quality and disease resistance of apples. HortScience 32:831-835.

Ferguson, I.B., and C.B. Watkins. 1989. Bitter pit in apple fruit. Hortic. Rev. 11:289-355. 1989.

Ferguson, I.B., and L.M. Boyd. 2002. Inorganic nutrients and fruit quality. p. 17-45. In Knee, M. (ed.) Fruit quality and its biological basis. Academic Press, Sheffield, UK.

Gaskell, M., and R. Smith. 2007. Nitrogen sources for organic vegetable crops. HortTechnology 17:431-441.

Herencia, J.F., J.C. Ruiz-Porras, S. Melero, P.A. Garcia-Galavis, E. Morillo, and C. Maqueda. 2007. Comparison between organic and mineral fertilization for soil fertility levels, crop management concentrations and yield. Agron. J. 99:973-983.

Johnson, D.S., M.J. Marks, and K. Pearson. 1987. Storage quality of 'Cox's Orange Pippin' apples in relation to fruit mineral composition during development. J. Hort. Sci. 62:17-25.

Lauri, P.É., and J.M. Lespinasse. 1999. Apple tree training in France: current concepts and practical implications. Fruits 54:441-449.

Mengel, K., and E.A. Kirkby. 2001. Principles of plant nutrition. Springer, Dordrecht, Netherlands.

Nava, G., and A.R. Dechen. 2009. Longterm annual fertilization with nitrogen and potassium affect yield and mineral composition of 'Fuji' apple. Scientia Agricola 66:377-385.

Neilsen, G.H., and D. Neilsen. 2003. Nutritional requirements of apple. p. 267-302. In Ferree, D.C. and Warrington, I.J. (eds.). Apples: Botany, production and uses. CABI, Oxfordshire, UK. 
Piestrzeniewicz, C., and K. Tomala. 2001. Some factors influencing storage ability of Jonagold apples. Acta Hortic. 564:435-442.

Roussos, P.A., and D. Gasparatos. 2009. Apple tree growth and overall fruit quality under organic and conventional orchard management. Scientia Horticulturae 123(2):247-252.

Saure, M.C. 2005. Calcium translocation to fleshy fruit: its mechanism and endogenous control. Scientia Horticulturae 105:65-89.

Stillianides, D., A. Simonis, , D. Sirgianides. 2002. Nutrition-fertilization of deciduous fruiting trees. Stamoulis, Athens, Greece.

Streif, J. 1996. Optimum harvest date for different apple cultivars in the 'Bodensee' area. $p$. 15-20. In De Jager, A., Johnson, D. and Hohn E. (eds.). Determination and prediction of optimum harvest date of apples and pears. European Communities, Luxemburg.

Van Der Boon. 1980. Prediction and control of bitter pit in apples. I. Prediction based on mineral leaf composition, cropping levels and summer temperatures. J. Hort. Sci. 55:307-312.
Vaugham, L. 2001. Statistical methods for the information professional: A Practical, Painless Approach to Understanding, Using, and Interpreting Statistics. Information today. New Jersey, USA.

Von Bennewitz, E., T. Cooper, C. Benavides, T. Losak, and J. Hlusek. 2011. Response of 'Jonagold' apple trees to $\mathrm{Ca}, \mathrm{K}$ and $\mathrm{Mg}$ fertilization in an andisol in southern Chile. J. Soil Sci. Plant Nutr. 11:71-81.

Von Bennewitz, E., T. Cooper, T. Losak, J. Hlusek, and M. Carrasco-Benavides. 2015. Effects of decreasing levels of $\mathrm{N}$ amendments on organic "Granny Smith" apple trees. J. Soil Sci. Plant Nutr. 15(4):979-990.

Weir, R.G., and G.C. Cresswell. 1991. Temperate and subtropical fruit and nut crops. Plant Nutrition Disorders. NSW Agriculture. Inkata Press, Melbourne, Australia.

Yuri, J.A, V. Lepe, y J.L. Vásquez. 2008. Intensificación de la carga vs. calidad de la fruta. Boletín Técnico. Centro de Pomáceas, Universidad de Talca, Talca, Chile. 